\title{
Lounaisen ulkosaaristomme väestönkehitys
}

Professori KNUT PIPPING

Ábo Akademi

Saaristoalueemme muodostavat monessa suhteessa erikoislaatuisen kulttuurimaantieteellisen alueen. Mutta saaristo ei ole mikään homogeeninen alue. Uudenmaan, Turun, Ahvenanmaan ja Pohjanmaan saaristot eroavat toisistaan maantieteellisesti melkoisesti ja lounaissaaristossamme on myöskin huomattavia alueellisia eroavuuksia. Luonteenomaista kaikille saaristoalueille kuitenkin on, että maisema on niin pirstoutunut, että minkäänlaisia yhtenäisiä viljelysalueita tai suuria asutuskeskuksia ei ole muodostunut. Yleisesti voidaan sanoa, että mitä kauemmaksi ulkosaaristoon menee, sitä pirstoutuneemmaksi muuttuu maisema ja sitä ahtaampia rajoja luonto asettaa asutukselle. Tämä heijastuu myös väestötilastossa. Koska hallinnolliset alueet saaristossa eivät kuitenkaan maantieteellisesti ole homogeenisia, ei se kuva, joka saadaan virallisen tilaston perusteella, ole erityisen selvä. Esim. Korppoossa on asutus osittain jakautunut monelle pienelle saarelle, osittain pääsaarelle. Elämisen mahdollisuudet ovat melko erilaisia eri osissa kuntaa. Jotta voisi yksityskohtaisemmin tutkia alueellisia eroavuuksia väestönkehityksessä olisi tietoja saatava pienemmistä yksiköistä kuin kunnista.

Stig Jaatinen on koko lounaissaaristosta tehnyt tällaisen yksityiskohtaisen tutkimuksen väestönkehityksestä ajalta 1905-1950. Tutkimus (joka on julkaistu Nordenskiöld-Samfundetin äskettäin ilmestyneessä SaaristoSuomen Kartastossa) näyttää että saaristo voidaan jakaa kolmeen eri alueeseen: sisäsaaristoon, välisaaristoon ja ulkosaaristoon. Ulkosaaristoksi hän laskee Brändön, Kumlingen, Sottungan ja Kökarin kunnat sekä Föglön, Vårdön, Iniön, Houtskarin, Korppoon, Nauvon ja Hiittisten kuntien uloimmat osat. Tällä alueella, jossa asutus on eniten hajallaan ja väestö eniten eristynyttä, väestönkato on ollut voimakkain viime vuosikymmenien aikana.

Tässä kirjoituksessa käsittelen väestönkehitystä Korppoossa, Houtskarissa, Iniössä, Kumlingessa, Brändössä, Sottungassa ja Kökarissa. Minua on kiinnostanut tutkia väestönmuutoksia ennen viime vuosisadan vaihteessa tapahtunutta voimakasta väestön vähenemistä sekä verrata ulkosaariston väestönkehitystä vastaavaan kehitykseen muualla Suomessa. Valitettavasti en ole voinut käytettävissä olevan aineiston vuoksi rajoittaa 
Ta u lu 1. Väkiluvun muutokset eräissä Lounais-Suomen saaristokunnissa $1750-1950$.

Table 1. Population changes in some parishes in the archipelago off the Finnish SW-coast, 1750-1950.

\begin{tabular}{|c|c|c|c|c|c|c|c|c|c|c|}
\hline \multirow{2}{*}{$\begin{array}{l}\text { Kunta } \\
\text { Parish }\end{array}$} & \multicolumn{5}{|c|}{ Abs. luvut - Number } & \multicolumn{5}{|c|}{ Indeksi - Index } \\
\hline & 1750 & 1800 & 1850 & 1900 & 1950 & 1750 & 1800 & 1850 & 1900 & 1950 \\
\hline 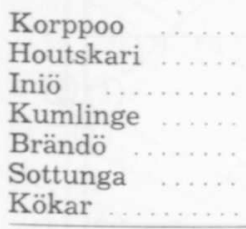 & $\begin{array}{r}1208 \\
964 \\
358 \\
435 \\
566 \\
137 \\
460^{1}\end{array}$ & $\begin{array}{r}1567 \\
1112 \\
371 \\
624 \\
890 \\
206 \\
502^{2}\end{array}$ & $\begin{array}{r}1957 \\
1557 \\
478 \\
736 \\
1043 \\
299 \\
494\end{array}$ & $\begin{array}{r}2631 \\
1991 \\
805 \\
1008 \\
1232 \\
409 \\
779\end{array}$ & $\begin{array}{r}2025 \\
1354 \\
595 \\
788 \\
927 \\
299 \\
683\end{array}$ & $\begin{array}{l}100 \\
100 \\
100 \\
100 \\
100 \\
100 \\
100\end{array}$ & $\begin{array}{l}130 \\
115 \\
104 \\
143 \\
157 \\
150 \\
109\end{array}$ & $\begin{array}{l}162 \\
162 \\
134 \\
169 \\
184 \\
218 \\
107\end{array}$ & $\begin{array}{l}218 \\
207 \\
225 \\
232 \\
218 \\
299 \\
169\end{array}$ & $\begin{array}{l}168 \\
140 \\
166 \\
181 \\
164 \\
218 \\
148 \\
\end{array}$ \\
\hline $\begin{array}{l}\text { Yht. - Total } \\
\text { Koko maaseutu } \\
\text { Rural Finland } \\
\begin{array}{lll}1 & \\
1749 \quad & 2 & 1805\end{array}\end{array}$ & 4128 & 5272 & 6564 & 8855 & 6671 & $\begin{array}{l}100 \\
100\end{array}$ & $\begin{array}{l}128 \\
196^{2}\end{array}$ & $\begin{array}{l}159 \\
382\end{array}$ & $\begin{array}{l}215 \\
580\end{array}$ & $\begin{array}{l}162 \\
681\end{array}$ \\
\hline
\end{tabular}

Taulu 2. Elävinä syntyneitä keskiväkiluvun tuhatta asukasta kohti, kunnittain.

Table 2. Live births per thousand inhabitants, by parish.

\begin{tabular}{|c|c|c|c|c|c|c|c|c|}
\hline & Ko & Ho & In & $\mathrm{Ku}$ & $\mathrm{Br}$ & So & Kö & $\begin{array}{l}\text { Koko } \\
\text { maaseutu } \\
\text { Rural } \\
\text { Finland }\end{array}$ \\
\hline $\begin{array}{l}1750-54 \\
1776-80 \\
1801-05 \\
1826-30 \\
1851-55 \\
1876-80 \\
1901-05 \\
1926-30 \\
1951-55\end{array}$ & $\begin{array}{l}34.2 \\
31.6^{1} \\
27.4 \\
27.5 \\
25.6 \\
27.8 \\
24.5 \\
17.6 \\
13.3\end{array}$ & $\begin{array}{l}35.2 \\
29.3^{2} \\
36.7 \\
29.0 \\
26.3 \\
27.9 \\
23.5 \\
11.7 \\
11.1\end{array}$ & $\begin{array}{l}31.9 \\
28.9 \\
28.3^{3} \\
27.4 \\
24.5 \\
33.7 \\
23.2 \\
11.1 \\
12.9\end{array}$ & $\begin{array}{l}39.6 \\
47.0 \\
45.1 \\
31.9 \\
27.4 \\
30.9 \\
21.7 \\
17.5 \\
14.3\end{array}$ & \begin{tabular}{r|r}
39.6 & \\
33.6 & \\
29.4 & \\
26.4 & \\
30.8 & \\
28.6 & \\
25.3 & \\
16.6 & \\
7.6 &
\end{tabular} & $\begin{array}{l}32.4 \\
33.5 \\
29.9 \\
51.3 \\
31.5 \\
29.0 \\
15.4 \\
20.8 \\
22.2\end{array}$ & $\begin{array}{r}40.8^{3} \\
36.2 \\
42.4 \\
36.4 \\
33.1 \\
15.8 \\
8.4\end{array}$ & $\begin{array}{l}45.2 \\
41.3 \\
38.4 \\
37.8 \\
36.3 \\
36.9 \\
32.4 \\
22.4 \\
22.0\end{array}$ \\
\hline \multicolumn{9}{|c|}{ Lähde - Source: Stierncreutz 1957, Taul. 7.} \\
\hline
\end{tabular}

tutkimusaluetta niin, että se kokonaan vastaisi sitä aluetta, jonka Jaatinen katsoo ulkosaaristoksi. Kolme tutkituista kunnista kuuluu näet osittain hänen mukaansa välisaaristoon.

Niin pitkälle kuin voidaan seurata väestönkehitystä on ulkosaariston väkiluku lisääntynyt paljon hitaammin kuin maaseudun väestö muualla Suomessa. Vuosien 1750 ja 1900 välillä Suomen maaseudun väestö kasvoi lähes kuusinkertaiseksi kun se ulkosaaristossa ainoastaan hiukan enemmän kuin kaksinkertaistui (taulu 1, kuvio 1). Mantereella maaseudun 


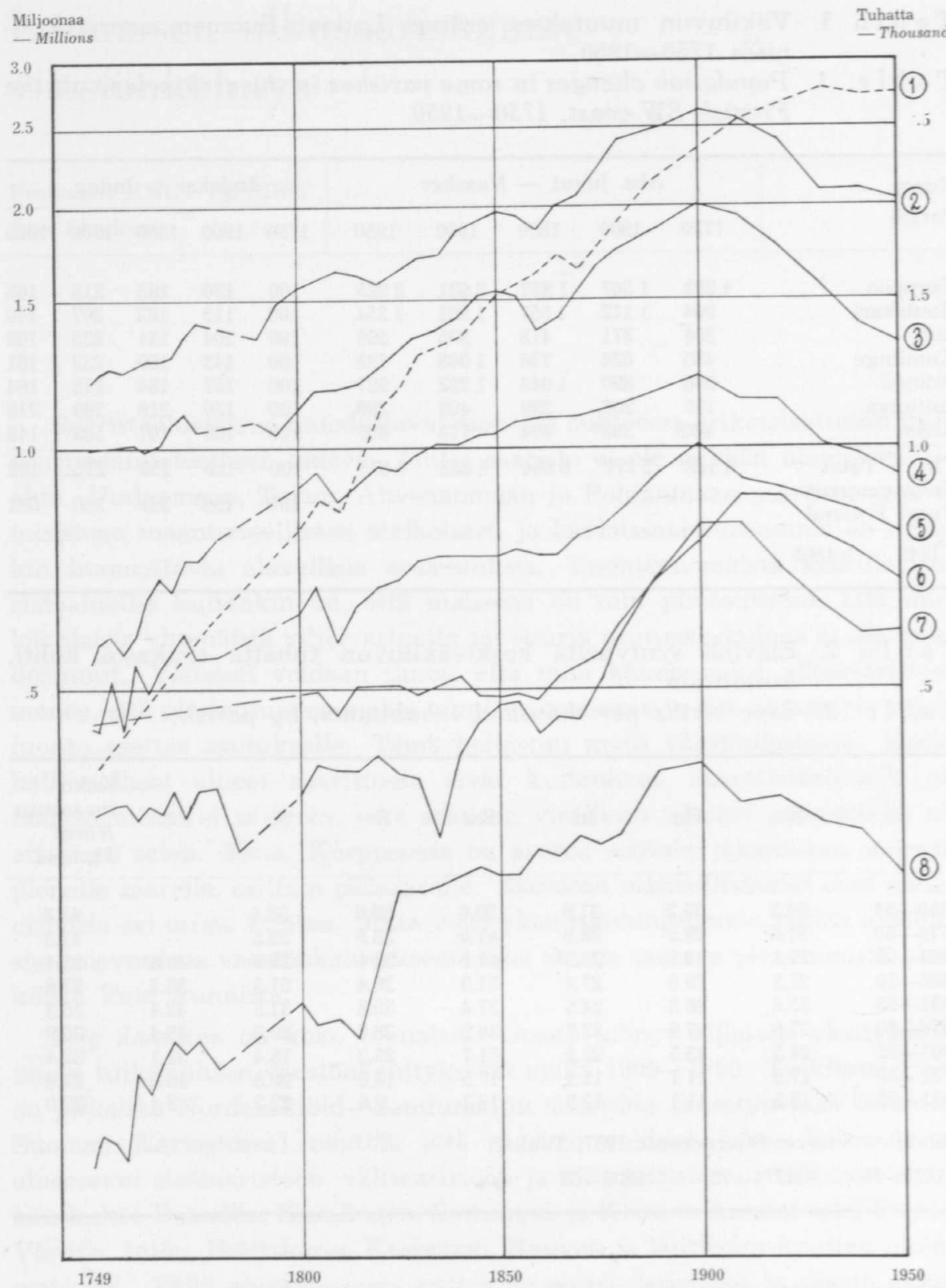

K uvi o 1. Väkiluvun kehitys $1749-1950$ seitsemässä ulkosaaristokunnassa (asteikko oikealla) ja Suomen maaseudulla (asteikko vasemmalla).

Fig. 1. Population increase $1749-1950$ in seven parishes in the archipelago off the Finnish SW-coast (right-hand scale) and in rural Finland (left-hand scale).

1 Maaseutu - Rural Finland, 2 Korppoo, 3 Houtskari, 4 Brändö, 5 Kumlinge, 6 Kökar, 7 Iniö, 8 Sottunga. 


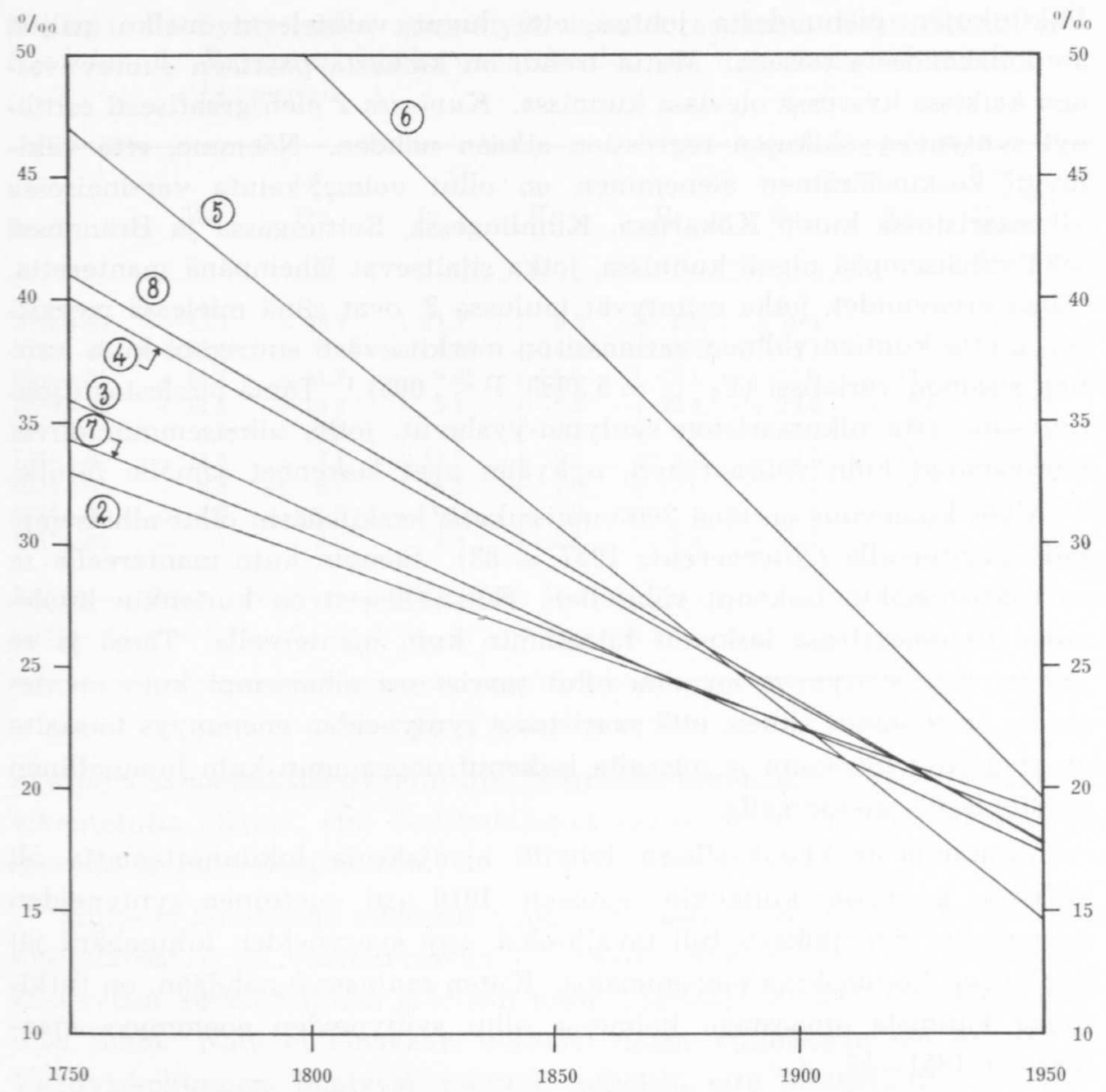

K uvio 2. Syntyvyyden regressio, kunnittain, 1750-1950.

Fig. 2. Regression of the crude birth rate, by parish, 1750-1950. 2. Korppoo, 3. Houtskari, 4. Brändö, 5. Kumlinge, 6. Kökar, 7. Iniö, 8. Sottunga.

väestönkasvu jatkui lähes muuttumatta vuoteen 1930 , jonka jälkeen väestön lukumäärä on jäänyt suurinpiirtein samalle tasolle. Ulkosaaristossa alkoi väestön lukumäärä jo heti vuosisadan vaihteen jälkeen laskea melko jyrkästi. Nykyään on ulkosaariston väestön lukumäärä lähes yhtä suuri kuin se oli 1800-luvun puolivälissä.

Eräässä julkaisemattomassa tutkimuksessa osoittaa Stierncreutz, että syntyneisyys jokaisena 5 -vuotiskautena vuodesta 1750 lähtien on ollut 5-10 promillea mantereen vastaavan luvun alapuolella (Stierncreutz 1957, s. 72). Tämä ilmenee myöskin taulusta 2, joka muodostaa osan Stierncreutzin syntyneisyysluvun vaihtelua esittävästä täydellisestä taulukosta. 
Väkilukujen pienuudesta johtuu, että luvut vaihtelevat melko paljon 5-vuotiskaudesta toiseen. Mutta trendi on kaikesta päättäen suoraviivainen kaikissa kyseessä olevissa kunnissa. Kuviossa 2 olen graafisesti esittänyt syntyneisyyslukujen regression aikaan nähden. Näemme, että väkiluvun keskimääräinen aleneminen on ollut voimakkainta varsinaisessa ulkosaaristossa kuten Kökarissa, Kumlingessa, Sottungassa ja Brändössä sekä vähäisempää niissä kunnissa, jotka sijaitsevat lähempänä manteretta. Nämä eroavuudet, jotka esiintyvät taulussa 2, ovat siinä mielessä merkitseviä, että kuntien välinen varianssi on merkitsevästi suurempi kuin kuntien sisäinen varianssi $\left(\mathrm{F}_{5} ._{\infty}=5.3983, \mathrm{P}<.005\right){ }^{1}$ Tämä puolestaan johtuu siitä, että ulkosaariston syntyneisyysluvut, jotka aikaisemmin olivat korkeammat kuin välisaariston, nykyään ovat laskeneet samalle tasolle.

Myös kuolevuus on tänä 200-vuotisaikana keskimäärin ollut alhaisempi kuin mantereella (Stierncreutz 1957, s. 83). Samoin kuin mantereella se on saaristossakin laskenut vähitellen. Suhteellisesti on kuitenkin kuolevuus ulkosaaristossa laskenut hitaammin kuin mantereella. Tämä ja se seikka, että syntyvyys on aina ollut saaristossa alhaisempi kuin mantereella, on johtanut siihen, että saaristossa syntyneiden enemmyys toisaalta on aina ollut pienempi ja toisaalta laskenut nopeammin kuin luonnollinen väestönlisäys mantereella.

Muutamia poikkeuksellisen lyhyitä ajanjaksoja lukuunottamatta oli kaikissa kunnissa kuitenkin vuoteen 1910 asti vuotuinen syntyneiden enemmyys. Sen jälkeen tuli tavalliseksi, että syntyneiden lukumäärä jäi kuolleiden lukumäärää pienemmäksi. Kuten taulusta 3 nähdään, on tutkituista kunnista ainoastaan kolmessa ollut syntyneiden enemmyys ajanjaksona $1951-55$.

Kun syntyneisyysluku ilmoitetaan promilleina keskiväkiluvusta, niin kuin edellä on tehty, on se, kuten tunnettua, riippuvainen väestön ikärakenteesta. Kun se koko tutkitun ajanjakson aikana on ollut ulkosaaristossa toisenlainen kuin mantereella, meidän täytyy eliminoida sen vaikutus saadaksemme selvän kuvan hedelmällisyydestä. Erikoishedelmällisyysluvut ja yleiset hedelmällisyysluvut osoittavat Stierncreutzin tutkimuksessa, että ulkosaariston alhainen syntyneisyysluku johtuu siitä, että saaristossa on ollut alhaisempi hedelmällisyys kuin mantereella (Stierncreutz 1957 , taulut 8 ja 9 s. 76). Ei ole helppoa sanoa onko aina ollut näin, koska vertailuja koko maan kanssa ei ole mahdollista suorittaa kuin vasta vuodesta 1866. Koska yleiset ja erikoishedelmällisyysluvut eivät nouse mainittavasti ulkosaaristossa siirryttäessä ajassa taaksepäin, kun taas ikäja-

${ }^{1}$ Kuviossa 2 oleva Kökarin regressiosuora ei ole täysin vertailukelpoinen muihin. Myöskään varianssianalyysissa ei Kökaria ole otettu huomioon. Kun ennen v. 1800 ei ole Kökarin osalta erikseen tietoja syntyneiden lukumääristä, on regressioyhtälö laskettu ajanjaksolta 1800-1950. Tämän johdosta on suora tullut kenties liian jyrkäksi. 
Taulu 3. Syntyneiden enemmyys tuhatta asukasta kohti, kunnittain. Table 3. Excess of births over deaths, per one thousand inhabitants, by parish.

\begin{tabular}{|c|c|c|c|c|c|c|c|c|}
\hline & Ko & Ho & In & $\mathrm{Ku}$ & $\mathrm{Br}$ & So & Kö & $\begin{array}{l}\text { Koko } \\
\text { maaseutu } \\
\text { Rural } \\
\text { Finland }\end{array}$ \\
\hline $\begin{array}{l}1750-54 \\
1776-80 \\
1801-05 \\
1826-30 \\
1851-55 \\
1876-80 \\
1901-05 \\
1926-30 \\
1951-55\end{array}$ & $\begin{array}{l}+13.1 \\
+12.0^{2} \\
+10.7 \\
+11.4 \\
+\quad 4.4 \\
+11.6 \\
+\quad 8.8 \\
+\quad 1.2 \\
+\quad .1\end{array}$ & $\begin{array}{c}+15.7 \\
+\quad 3.7^{3} \\
+11.2 \\
+10.2 \\
+\quad 3.2 \\
+\quad 7.1 \\
+\quad 6.7 \\
-\quad 1.9 \\
-\quad 3.9\end{array}$ & $\begin{array}{l}+11.2 \\
+\quad 7.4 \\
+\quad 9.0^{4} \\
+\quad 5.1 \\
-\quad .8 \\
+11.7 \\
+\quad 6.2 \\
+\quad 6.8 \\
+\quad 1.4\end{array}$ & $\begin{array}{r}+\quad 9.5 \\
+14.2 \\
+21.0 \\
+16.5 \\
+\quad 6.5 \\
+\quad 10.6 \\
+\quad 7.0 \\
+\quad .9 \\
+\quad 2.4\end{array}$ & $\begin{array}{r}+\quad 6.9 \\
+14.0 \\
+12.1 \\
+12.1 \\
+\quad 4.7 \\
+\quad 7.5 \\
+10.0 \\
+\quad .7 \\
-\quad 7.4\end{array}$ & $\begin{array}{c}+19.1 \\
-1.1 \\
+11.0^{4} \\
+28.8 \\
+\quad 7.4 \\
+\quad 9.6 \\
+\quad 3.5 \\
+\quad 1.8 \\
+\quad 5.7\end{array}$ & $\begin{array}{r}+11.9 \\
+\quad 9.5 \\
+\quad 7.7 \\
+17.8 \\
+\quad 9.0 \\
-\quad .2 \\
-\quad 2.5\end{array}$ & $\begin{array}{l}+17.1^{1} \\
+15.3 \\
+13.7 \\
+13.6 \\
+8.1 \\
+14.2 \\
+13.2 \\
+7.7 \\
+12.5\end{array}$ \\
\hline \multicolumn{9}{|c|}{ 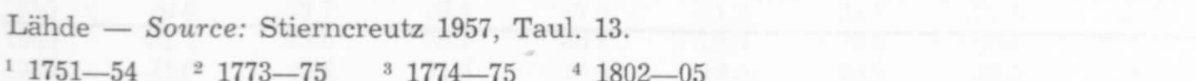 } \\
\hline
\end{tabular}

kautuma samanaikaisesti muuttuu progressiivisemmaksi, näyttää sen takia oikeutetulta olettaa, että hedelmällisyys myös ennen on ollut alhaisempi saaristossa kuin mantereella.

Mutta ei ainoastaan alhainen syntyvyys vaan myös muuttoliike on pitänyt ulkosaariston väestönkasvun alhaisena. Nykypäivien "maaltapakoa koskevissa keskusteluissa pidetään usein itsestään selvänä, että tämä olisi uusi ilmiö. Näin ei ainakaan ulkosaaristossa kuitenkaan ole asianlaita. Yksityiskohtainen analyysi näyttää selvästi, että lähtömuutto jo 1700 luvulla ainakin ajoittain oli huomattavasti suurempi kuin tulomuutto. ${ }^{1}$

Koska meillä ei ennen v. 1880 ole virallista muuttoliiketilastoa, on vaikea muodostaa käsitystä lähtö- ja tulomuuton suhteellisesta suuruudesta ennen tätä. Kuitenkin on melko helppoa väkilukutietojen sekä syntyneiden ja kuolleiden lukumäärän perusteella laskea muuttoliikkeen nettotulos. Stierncreutz on tehnyt tämän jokaiselle 5-vuotiskaudelle vuodesta 1750 alkaen. Hänen lukusarjoistaan nähdään, että lähtömuutto on melkein koko ajan ylittänyt tulomuuton kaikissa kunnissa (vrt. taulu 4). 1800luvun puoliväliin asti vaihtelee muuttotappio niin voimakkaasti, että on vaikeata puhua mistään yhtenäisestä tendenssistä. Mutta 1800-luvun loppupuolella pyrkii muuttotappio lisääntymään lukuunottamatta Kumlingen ja Brändön kuntia, joissa se viimeisen viiden vuosikymmenen ajan on pysynyt samalla tasolla. Ensimmäiseen maailmansotaan saakka oli muutto-

1 Tutkimukset, joita en ole vielä vienyt loppuun, näyttävät osoittavan, että näin on ollut asian laita myös 1500- ja 1600-luvuilla, ehkä keskiajallakin. 
$\mathrm{T}$ a ulu 4. Muuttovoitto ja -tappio tuhatta asukasta kohti, kunnittain. Table 4. Migration gains and losses, per thousand inhabitants, by parish.

\begin{tabular}{lccccccc}
\hline & Ko & Ho & In & Ku & Br & So & Kö \\
\hline $1750-54$ & -4.9 & -3.7 & -5.0 & +19.0 & -1 & -5.9 & \\
$1776-80$ & $+4.5^{2}$ & $-25.1^{3}$ & -6.3 & -12.8 & -1.6 & -14.5 & \\
$1801-05$ & -6.1 & - & & -6.2 & -2.9 & -21.9 & \\
$1826-30$ & -3.4 & -.9 & -7.1 & -5.1 & -4.0 & -28.1 & -14.3 \\
$1851-55$ & -8.0 & +.1 & +3.3 & -4.3 & +.8 & -8.0 & -6.9 \\
$1876-80$ & +3.4 & +.9 & +15.0 & -1.5 & -4.3 & -3.0 & -1.4 \\
$1901-05$ & -.7 & +.1 & -9.7 & -4.4 & -6.9 & -7.0 & -3.4 \\
$1926-39$ & -7.9 & -3.6 & -3.2 & -4.2 & -4.8 & +3.8 & -6.2 \\
$1951-55$ & -13.5 & -5.3 & -7.9 & -5.5 & -4.8 & -15.7 & -7.1
\end{tabular}

Lähde - Source: Stierncreutz 1957, Taul. 17.

${ }^{1} 1751-54 \quad{ }^{2} 1773-75 \quad{ }^{3} 1774-75$

Ta ulu 5. Vuosittain solmittuja avioliittoja tuhatta asukasta kohti, kunnittain.

Table 5. Annually contracted marriages per thousand inhabitants, by parish.

\begin{tabular}{|c|c|c|c|c|c|c|c|c|}
\hline & Ko & Ho & In & $\mathrm{Ku}$ & $\mathrm{Br}$ & So & Kö & $\begin{array}{l}\text { Koko } \\
\text { maaseutu } \\
\text { Rural } \\
\text { Finland }\end{array}$ \\
\hline $\begin{array}{l}1750-54 \\
1776-80 \\
1801-05 \\
1826-30 \\
1851-55 \\
1876-80 \\
1901-05 \\
1926-30 \\
1951-55\end{array}$ & \begin{tabular}{l|l|}
7.6 \\
$5.0^{2}$ \\
7.3 \\
8.6 \\
8.2 \\
7.0 \\
4.7 \\
6.2 \\
5.4
\end{tabular} & $\begin{array}{l}9.2 \\
5.1^{3} \\
7.5 \\
7.6 \\
6.9 \\
7.0 \\
4.5 \\
5.5 \\
6.4\end{array}$ & \begin{tabular}{l|}
10.6 \\
10.0 \\
\\
6.6 \\
2.9 \\
7.0 \\
4.0 \\
3.5 \\
5.6
\end{tabular} & $\begin{array}{l}7.3 \\
8.0 \\
9.3 \\
7.7 \\
6.7 \\
7.9 \\
4.2 \\
6.7 \\
5.2 \\
\end{array}$ & $\begin{array}{r}6.9^{1} \\
3.8 \\
6.6 \\
6.3 \\
10.2 \\
7.7 \\
6.5 \\
4.5 \\
5.7\end{array}$ & $\begin{array}{r}7.4 \\
14.5 \\
2.0 \\
4.9 \\
7.4 \\
6.7 \\
3.0 \\
6.3 \\
7.9 \\
\end{array}$ & $\begin{array}{l}\cdots \\
\cdots \\
3.8 \\
8.1 \\
9.8 \\
9.4 \\
5.7 \\
4.0\end{array}$ & \begin{tabular}{r|}
10.1 \\
8.9 \\
7.8 \\
8.4 \\
7.7 \\
7.9 \\
6.7 \\
7.2 \\
7.7 \\
\end{tabular} \\
\hline \multicolumn{9}{|c|}{ Lähde - Source: Stierncreutz 1957, Taul. 5.} \\
\hline
\end{tabular}

tappio tavallisesti pienempi kuin syntyneiden enemmyys, mutta sen jälkeen on muuttotappio melkein poikkeuksetta ylittänyt syntyneiden enemmyyden niissä kunnissa, joissa tällainen voidaan osoittaa.

Nämä luvut muuttoliikkeen nettotuloksesta eivät kuitenkaan anna käsitystä muuttoliikkeen laajuudesta. De Geer on tehnyt erikoistutkimuksen (Saaristo-Suomen Kartasto, kartta 7), jossa hän osoittaa että tämä kuitenkin jo 1800-luvun alussa oli melko huomattavaa ja Stierncreutzin lukusarjat vuodesta 1880 lähtien näyttävät, että tulomuutto oli keskimäärin 
T a u lu 6. 0-14-vuotiaitten prosentuaalinen osuus koko väestöstä 17501950, kunnittain.

Table 6. Percentage aged 0-14, 1750-1950, by parish.

\begin{tabular}{|c|c|c|c|c|c|c|c|c|}
\hline & \multicolumn{7}{|c|}{ A. Miehet-Men } & \multirow{2}{*}{$\begin{array}{l}\text { Koko } \\
\text { maaseutu } \\
\text { Rural } \\
\text { Finland }\end{array}$} \\
\hline & Ko & Ho & In & $\mathrm{Ku}$ & $\mathrm{Br}$ & So & Kö & \\
\hline 1751 & 38.1 & 37.9 & 29.9 & 39.0 & 32.0 & 36.6 & $34.5^{1}$ & 38.7 \\
\hline 1805 & 36.1 & 33.6 & 32.1 & 37.5 & 32.9 & 41.6 & 28.3 & $37.1^{2}$ \\
\hline 1850 & 33.0 & 35.3 & 35.3 & 32.3 & 30.9 & 33.8 & 35.9 & 35.4 \\
\hline 1900 & 33.9 & 28.7 & 30.9 & 34.0 & 35.5 & 34.7 & 37.7 & 35.9 \\
\hline \multirow[t]{2}{*}{1950} & 28.9 & 24.1 & 28.8 & 21.3 & 23.2 & 28.8 & 25.4 & 32.0 \\
\hline & \multicolumn{7}{|c|}{ B. Naiset-Women } & \\
\hline 1751 & 37.0 & 32.0 & 31.4 & 42.0 & 29.3 & 28.6 & 33.3 & 35.8 \\
\hline 1805 & 32.3 & 30.0 & 26.7 & 36.4 & 31.4 & 38.3 & 32.1 & 35.4 \\
\hline 1850 & 29.5 & 33.7 & 26.4 & 27.6 & 31.2 & 31.8 & 33.5 & 33.7 \\
\hline 1900 & 31.1 & 28.0 & 28.1 & 33.3 & 29.9 & 35.2 & 35.5 & 34.3 \\
\hline 1950 & 24.0 & 20.6 & 21.6 & 20.8 & 19.5 & 19.6 & 26.5 & 28.1 \\
\hline
\end{tabular}

Taulu 7. 15-24-vuotiaitten prosentuaalinen osuus koko väestöstä 1750 - 1950, kunnittain.

Table 7. Percentage aged 15-24, 1750-1950, by parish.

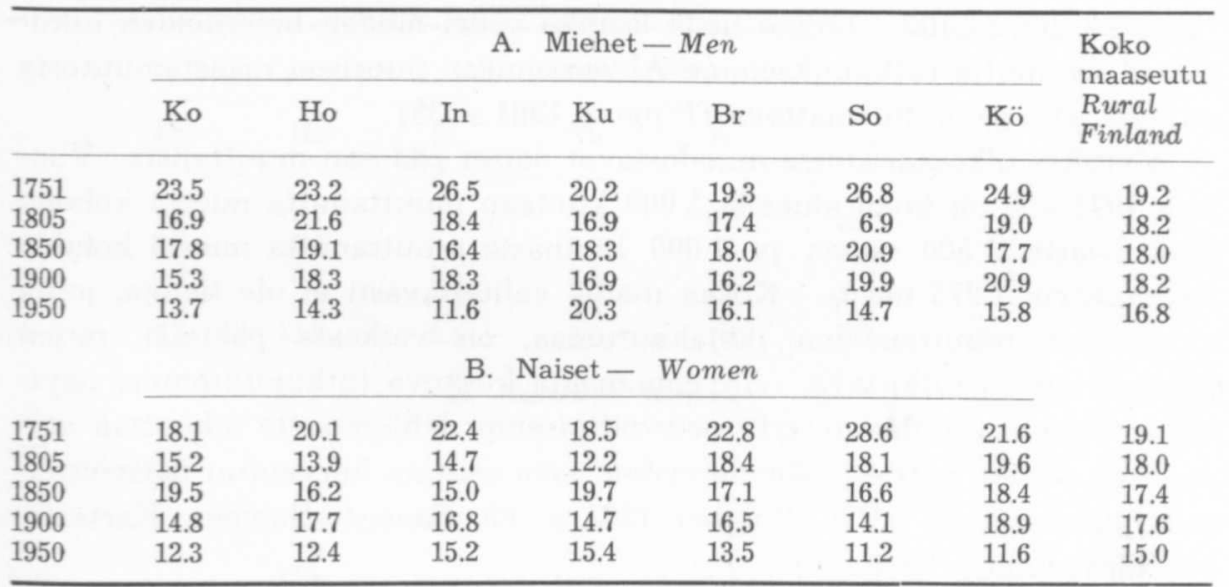

10 promillen ja lähtömuutto 13 promillen paikkeilla. Nämä luvut vaikuttavat varsin korkeilta ja huomattava on, että sekä tulo- että lähtömuuttoluvut ovat pyrkineet mieluummin nousemaan kuin alenemaan. ${ }^{1}$ Saariston yleisen kehityksen perusteella olisi pikemmin odottanut päinvastaista suuntausta. Syynä kokonaismuuton laajuuteen lienee kaikesta päätellen

${ }^{1}$ On hankalaa muodostaa luotettavaa käsitystä trendistä, koska puutteellinen muuttorekisteröinti 1920 - ja 1930-luvulla hämmentää kuvaa. 
Taulu 8. 25-44-vuotiaitten prosentuaalinen osuus koko väestöstä 1750-1950, kunnittain.

Table 8. Percentage aged 25-44, 1750-1950, by parish.

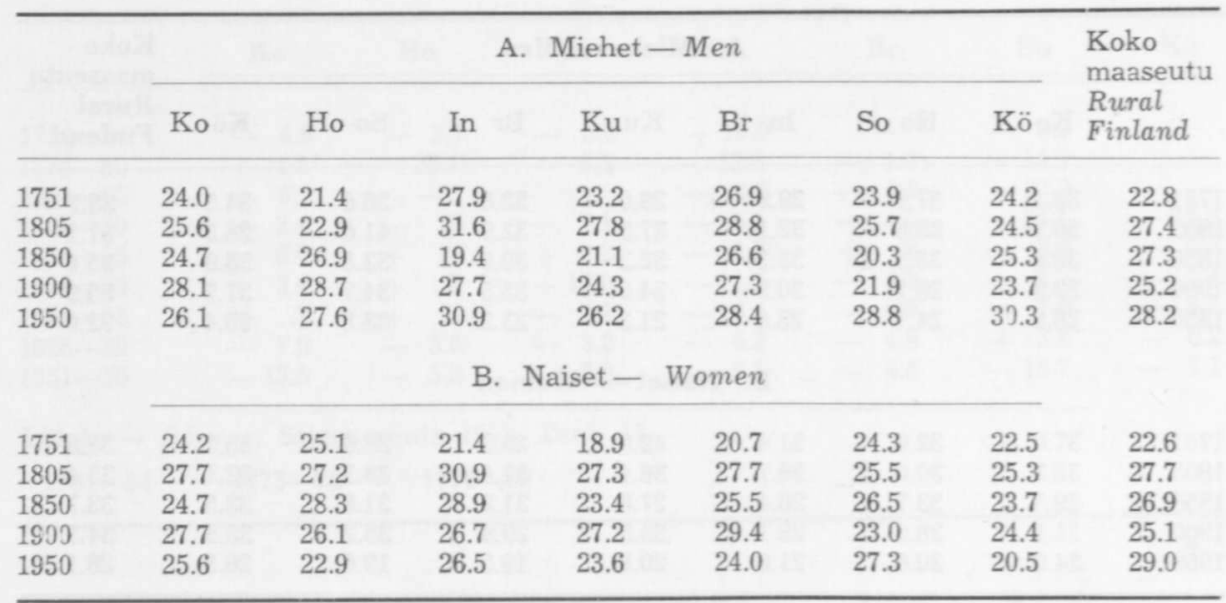

se, että samat yksilöt melko suuressa määrin muuttavat edestakaisin saaristossa olevan kotipaikkansa sekä mantereella tai Ruotsissa sijaitsevien työpaikkojen välillä. Emme tiedä kuinka suuri näiden henkilöiden lukumäärä on, mutta tutkimuksemme Ahvenanmaan nuorison maastamuutosta näyttää, että se on huomattava (Pipping 1961 s. 38).

Myöskin ulkosaaristossa muodostavat naiset pääosan muuttajista. Vuosina 1921-55 oli koko alueella 1000 kuntaan muuttanutta miestä kohden keskimäärin 1500 naista ja 1000 kunnasta muuttanutta miestä kohden keskimäärin 1275 naista. Koska meillä valitettavasti ei ole tietoja, jotka valaisisivat muuttaneiden ikäjakautumaa, on vaikeata päätellä, miten nämä luvut on tulkittava. Ahvenanmaata koskeva tutkimuksemme näyttää kuitenkin osoittavan, että naisvoittoisempi lähtömuutto aiheuttaa naimaiässä olevien naisten vähemmyyden, joka osittain korvautuu naisvoittoisella tulomuutolla (Vrt. Pipping 1961 s. 69, Saaristo-Suomen Kartasto, väestöpyramidit, kartta 6).

Luultavasti on oikein olettaa, että pääosa muuttaneista on nuorisoa, joka toistaiseksi ei ole ehtinyt muodostaa perhettä. Seurauksena tästä voi olla suhteellisen alhainen avioituvuus (taulu 5). Tämä ei kuitenkaan ole aivan varmaa, koska yleinen avioituneisuusluku ilmoitetaan koko väkiluvun perusteella, ja vanhimmat ikäluokat ovat suhteellisen suuria tutkituissa kunnissa.

Ikäjakautuman muutoksia esittävät taulukot (taulut 6-10) osoittavat, että ikäjakautuma yleisesti ei ole ollut niin suotuisa ulkosaaristossa kuin mantereella ja että nuorimmat ikäluokat vuosisadan vaihteesta lähtien ovat vähentyneet nopeammin kuin yleensä maaseudulla. Yksityiskohtai- 
Taulu 9. 45-64-vuotiaitten prosentuaalinen osuus koko väestöstä $1750-1950$, kunnittain.

Table 9. Percentage aged 45-64, 1750-1950, by parish.

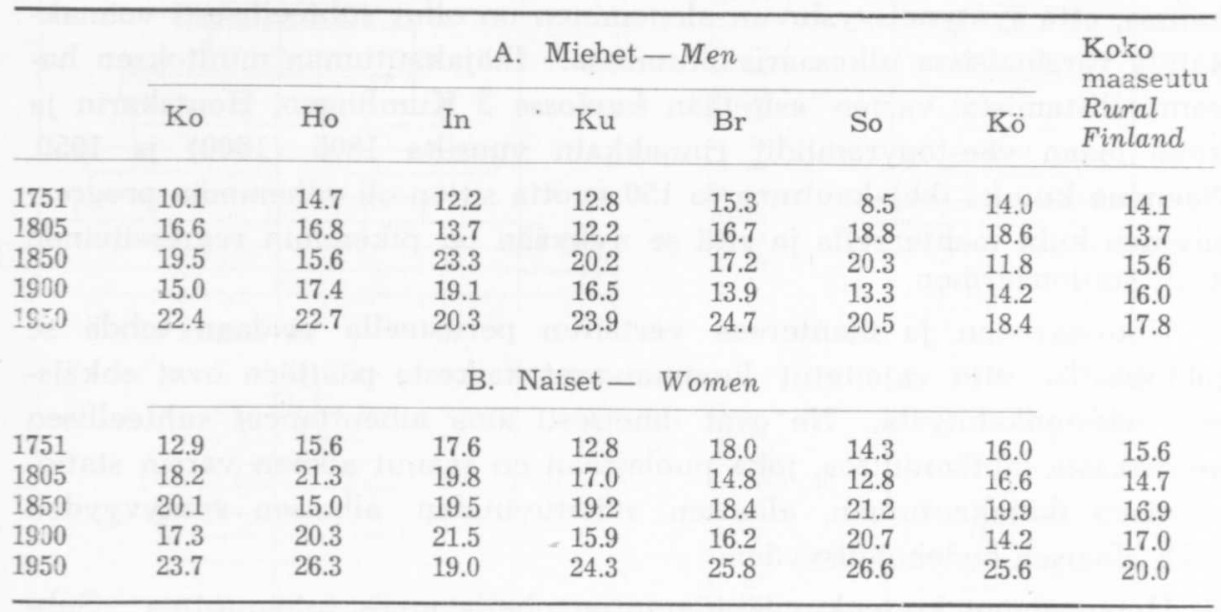

Taulu 10. 65-vuotiaitten ja sitä vanhempien osuus koko väestöstä 1750 - 1950, kunnittain.

Table 10. Percentage aged 65 and over, 1750-1950, by parish.

\begin{tabular}{|c|c|c|c|c|c|c|c|c|}
\hline & \multicolumn{7}{|c|}{ A. Miehet-Men } & \multirow{2}{*}{$\begin{array}{l}\text { Koko } \\
\text { maaseutu } \\
\text { Rural } \\
\text { Finland }\end{array}$} \\
\hline & Ko & Ho & In & $\mathrm{Ku}$ & $\mathrm{Br}$ & So & Kö & \\
\hline $\begin{array}{l}1751 \\
1805 \\
1850 \\
1900 \\
1950\end{array}$ & $\begin{array}{l}4.3 \\
4.8 \\
4.9 \\
7.6 \\
8.8\end{array}$ & $\begin{array}{r}2.7 \\
5.1 \\
3.1 \\
7.0 \\
11.3\end{array}$ & $\begin{array}{r}3.4 \\
4.2 \\
5.6 \\
3.9 \\
8.4 \\
\text { B. }\end{array}$ & $\begin{array}{r}4.8 \\
5.6 \\
8.1 \\
8.4 \\
8.3 \\
\text { iset- }\end{array}$ & $\begin{array}{r}6.5 \\
4.3 \\
7.2 \\
7.0 \\
7.6 \\
\\
\end{array}$ & $\begin{array}{r}4.2 \\
6.9 \\
4.7 \\
10.2 \\
7.1\end{array}$ & $\begin{array}{r}2.6 \\
5.5 \\
9.3 \\
3.6 \\
10.1\end{array}$ & $\begin{array}{l}5.1 \\
3.6 \\
3.7 \\
4.7 \\
5.2\end{array}$ \\
\hline $\begin{array}{l}1751 \\
1805 \\
1850 \\
1900 \\
1950\end{array}$ & $\begin{array}{r}7.8 \\
6.7 \\
6.1 \\
9.1 \\
14.2\end{array}$ & $\begin{array}{r}7.1 \\
7.6 \\
6.8 \\
7.9 \\
17.8\end{array}$ & $\begin{array}{r}7.1 \\
7.8 \\
10.2 \\
6.9 \\
17.7\end{array}$ & $\begin{array}{r}7.0 \\
7.1 \\
10.0 \\
8.8 \\
15.9\end{array}$ & $\begin{array}{r}9.2 \\
7.7 \\
7.9 \\
7.9 \\
17.2\end{array}$ & $\begin{array}{r}4.3 \\
5.3 \\
4.0 \\
7.0 \\
15.4\end{array}$ & $\begin{array}{r}6.5 \\
6.4 \\
4.5 \\
7.0 \\
15.8\end{array}$ & $\begin{array}{l}7.0 \\
4.2 \\
5.1 \\
6.0 \\
7.9\end{array}$ \\
\hline $\begin{array}{l}\text { Lähde } \\
{ }^{1} 1749\end{array}$ & $\begin{array}{c}\text { - Sourc } \\
{ }^{2} 1800\end{array}$ & tiernc & 195 & ul. 7 . & & & & \\
\hline
\end{tabular}

nen eri kuntien välinen vertailu tutkitulla alueella osoittaa myös, että ikäjakautuma lähempänä manteretta sijaitsevissa kunnissa koko ajanjakson aikana pyrkii jäämään hieman epäsuotuisammaksi kuin kauempana olevissa kunnissa. Vuonna 1950 olivat tutkittujen kuntien väestöpyramidien eroavuudet hyvin pieniä (vaikkakin lähempänä manteretta olevissa kun- 
nissa oli vähiten progressiivinen jakautuma), joten vanheneminen on ollut suhteellisesti voimakkainta niissä kunnissa, jotka sijaitsevat kauimpana mantereesta. Tämä toteamus käy yhteen edellä esitettyjen havaintojen kanssa, että syntyneisyysluvun aleneminen on ollut suhteellisesti voimakkainta varsinaisissa ulkosaaristokunnisșa. Ikäjakautuman muutoksen havainnollistamista varten esitetään kuviossa 3 Kumlingen, Houtskarin ja koko maan väestöpyramiidit rinnakkain vuosilta 1805 (1800) ja 1950. Näemme kuinka ikäjakautuma jo 150 vuotta sitten oli vähemmän progressiivinen kuin mantereella ja että se nykyään on pikemmin regressiivinen kuin stationäärinen.

Ulkosaariston ja mantereen vertailun perusteella voidaan tehdä se johtopäätös, että rajoitetut luonnonvarat kaikesta päättäen ovat ehkäisseet väestönkehitystä. $\mathrm{Ne}$ ovat ilmeisesti aina aiheuttaneet suhteellisen voimakasta lähtömuuttoa, joka puolestaan on saanut aikaan varsin stationäärisen ikäjakautuman, alhaisen avioituvuuden, alhaisen syntyvyyden sekä alhaisen hedelmällisyyden.

Huomaamme kuitenkin lähtömuuton ohella myös tulomuuttoa. Suhteellisesta köyhyydestään huolimatta on ulkosaaristolla ollut vetovoimaa, joka ulottuu aina Pohjanmaalle saakka. Varsinkin aikaisemmin, ennenkuin luontaistalouden merkitys vielä oli vähentynyt, ulkosaaristossa (verrattuna moniin muihin seutuihin) vallitsi tietynlainen hyvinvointi sikäli, että nälkää nähtiin harvemmin kuin esim. Itä- ja Pohjois-Suomessa.

Kuten De Geer on osoittanut on tämä muuttoliike - ainakin yleisesti katsottuna ja pitkällä tähtäimellä - ollut luonteeltaan läpikulkuliikennettä, joka on suuntautunut lounaisesta koilliseen ja päinvastoin (SaaristoSuomen Kartasto, kartta 7). Minulla ei ole ollut riittävästi tietoja selvittääkseni missä määrin tulomuuttoon ja lähtömuuttoon osallistuvat henkilöt ovat olleet samoja henkilöitä, mutta ne sukututkimukset, joita olen suorittanut Kumlingessa, viittaavat siihen, että näin on ainoastaan osittain ollut asianlaita. Muuttomekanismi on pikemminkin ollut se, että poismuuttaneiden tilalle on tullut samanikäisiä ja aikoinaan kuntaan muuttaneiden, sittemmin poismuuttaneiden lasten ja lastenlasten tilalle vuorostaan on tullut uusia tulijoita.

Kuten Jaatinen on osoittanut voidaan 1800-luvulla tapahtunut väestönkasvu osaksi selittää viittaamalla asutuksen laajentumiseen (Jaatinen 1960). Lukuisat pienet saaret ulkosaariston uloimmissa osissa joutuivat asutuksen kohteeksi tänä aikana, mikä taas puolestaan suureksi osaksi johtui siitä, että suolasilakan kysyntä lisääntyi, kun mantereen väestö kasvoi. Asutus oli laajimmillaan 1900-luvun ensimmäisen vuosikymmenen aikana. Sen jälkeen on kauempana sijaitsevasta asutuksesta vähitellen luovuttu. Tämä prosessi, joka vielä jatkuu, näyttää tapahtuvan melko nopeasti ja on mahdollista, että kaukana ulkosaaristossa sijaitsevat pienimmät kylät tyhjenevät väestöstä, kun nykyinen aktiivinen sukupolvi kuolee. 
Teollistuminen, siirtyminen rahatalouteen ja liikenneyhteyksien yhä kasvava merkitys on ollut syynä siihen, että ulkosaariston asema on vähitellen huonontunut. Supistuneet toimeentulomahdollisuudet ulkosaariston perinteellisissä elinkeinoissa ja vaikeiden liikenneyhteyksien aiheuttama muiden ansiomahdollisuuksien puute on johtanut siihen, että ulkosaaristo nykyään kuuluu maamme köyhimpiin seutuihin (vrt. Wahlbeck 1955).

\section{Kirjallisuus}

Painetut 1 ähteet:

1. Suomen virallinen tilasto VI: Väestötilastot.

2. Jaatinen, S.: Expansion and retreat of settlement in the southwestern archipelago of Finland, Fennia 84, Helsinki 1960.

3. Nordenskiöld-Samfundet. Saaristo-Suomen Kartasto, Helsinki 1961.

4. Pipping, K. \& Pipping-van Hulten, I. E.: Den åländska ungdomens emigration, Mariehamn 1961.

5. Wahlbeck, L.: Om inkomstnivåns geografi i Finland, Helsingfors 1955.

Painamattomat 1 ähteet:

6. Helle, T.: Turun saariston väestönkehitys 1910-1955. Pro gradu-tutkielma, Turun yliopisto 1957 .

7. Stierncreutz, P.: Befolkningsutvecklingen i sex kommuner i sydvästra Finlands skärgård, Pro gradu-avhandling, Åbo Akademi 1957.

8. Stierncreutz, P.: Befolkningsförhållandena i sju skärgårdskommuner i Finland år 1950. Inst. för samhällsforskning Åbo Akademi.

9. Korppoon, Houtskarin, Iniön, Kumlingen, Brändön, Sottungan ja Kökarin seurakuntien arkistot: Väkilukutiedot 1750-1950.

\section{Summary:}

Population Development of the Outer Archipelago in SW Finland

\section{By KNUT PIPPING}

Åbo Akademi

The archipelago off the Finnish SW coast is geographically a unique region, which, however, is not homogeneous. As Jaatinen has shown (3), it can be divided into three distinct regions: the inner, central and outer archipelago. This paper attempts to analyse changes in the demography of the outer region since the middle of the 18 th century.

In 1900 the population of the outer archipelago had only doubled since 1750, while the population of rural Finland had increased six times (Tab. 1). Shortly after 1900 the island population began to decrease rapidly, and it is now about as large as in 1850. In rural Finland the growth continued till 1930, and the population figure has since then remained virtually unchanged. 
Since 1750 the crude birth rate of the outer archipelago has remained 5-10\% lower than on the mainland, and has gradually fallen (Tab. 2, Fig. 2). The decrease has been heaviest in the outermost communities (Kökar, Kumlinge, Sottunga, Brändö). Also the crude death rate has constantly been lower than on the mainland, but it has decreased less in the archipelago than elsewhere in rural Finland. Thus the excess of births over deaths has always been less in the archipelago; and after 1910 the number of deaths have usually exceeded the number of births (Tab. 3).

Analysis of the specific fertility rates shows that the fertility probably always has been lower in the islands than on the mainland $(6, \mathrm{pp} .6 \mathrm{ff}$.). It is, however, not chiefly the low fertility, but the heavy migration, which has retarded the growth of the island population. During almost every five-year period since 1750 the outmigrants have outnumbered the in-migrants (Tab. 4.).

Both in- and out-migration seem to have been rather heavy at least since the early 19 th century (3, map 7 ). Especially young people move back and forth between their homes in the archipelago and the towns, before they finally settle down. Women move more than men; in 1921-55 there were 1500 female per 1000 male out-migrants and 1275 female per 1000 male in-migrants. One consequence hereof is a low nuptiality rate (Tab. 5), another an unfavourable age distribution. The population pyramids, which already 150 years ago were less progressive than on the mainland, have now become almost regressive; and the further out we go, the worse they look (Tab. 6-10, Fig. 3).

The main reason for this adverse development is the archipelago's changing economic role. As long as subsistence economy prevailed everywhere in rural Finland, its chief product, salt herring, was in great demand; and till the beginning of this century living conditions in the archipelago did not compare unfavourably with those of other regions. But industrialization, the transition to money economy and the rising standard of living elsewhere have made living in the islands to look less attractive than before, and also made it more difficult for the islanders to earn their livelihood. 